\title{
Genetie Variations of Blood Groups and Biochemical Polymorphisms in NIH Miniature Pigs
}

\author{
Takao Oishi, Hiroyuki Maruno*, Hiroshi Kawaida*, Kaoru Sakamoto** \\ and Hiroshi Ujino***
}

National Institute of Agrobiological Resources,

Tsukuba Norinkenkyudanchi 305

*Kagoshima Prefectural Animal Husbandry Experiment Station,

Kokubu 899-44

* Sakura National Hospital, Sakura 285

**South Japan Grain Terminal Ltd.,Kagoshima 891-01

\begin{abstract}
The genetic variations of blood groups and biochemical polymorphisms in NIH miniature pigs were investigated in this study. The blood samples were collected from ten animals ( 6 males and 4 females) of this strain which was maintained in Kagoshima Prefectural Animal Husbandry Experiment Station. Blood types investigated comprised eight blood groups, five serum proteins, five red cell enzymes and two serum allotypes, 20 loci in total.

The results were as follows.

1) $\mathrm{NIH}$ miniature pigs showed polymorphic variations at $\mathrm{A}, \mathrm{F}, \mathrm{G}, \mathrm{H}, \mathrm{K}, \mathrm{O}, \mathrm{Pa}, \mathrm{Hp}, \mathrm{PHI}, \mathrm{EsD}, \mathrm{PSA}-1$ and PSA-II, 12 loci in total. When the gene frequencies in NIH miniature pigs were compared with those in the four miniature pig strains of Ohmini, Pitman-Moore, Göttingen and CLAWN-mini, NIH miniature strain showed characteristic frequencies in $\mathrm{A}, \mathrm{H}, \mathrm{K}, \mathrm{L}$ and $\mathrm{Pa}$ loci.

2) The genetic variability of NIH miniature pigs based on the gene frequencies of 20 blood type loci was higher than those of Ohmini and CLAWN-mini, and equal to Göttingen and Pitman-Moore.

3) Using the gene frequencies at the 20 loci, the genetic distances between NIH miniature pigs and seventeen pig breeds were calculated on the basis of the formulae of Rogers (1972) and Nei (1975), and the dendrograms showing genetic similarities among eighteen pig populations were prepared. NIH miniature pigs showed far genetic distances from Chinese pig breeds and relatively close distances to Landrace, Hampshire and Pitman-Moore among Euro-American breeds. It was clarified from the dendrogram that NIH miniature pigs belonged to Euro-American pig group, and was situated at the furthest distance among Euro-American breeds.
\end{abstract}

Key words : NIH miniature pigs, blood groups, biochemical polymorphism, genetic variability, genetic distance

\section{N I H ミニブタの血液型および蛋白質型特性}

\section{大石 孝雄・丸野 弘幸*・川井田 博*・ 坂本 薰 ${ }^{* *}$ ・宇治野 裕 $^{* *}$}

農林水産省農業生物資源研究所、筑波農林研究団地、つくば市 305

*鹿児島県畜産試験場、国分市 899-44

**国立佐倉病院、佐倉市 285

*** 南日本グレーンセンター、鹿児島市 891-01 
近年小型豚が、医学、畜産学分野の研究用実験動物之 して注目されている。世界的にみて、米国を中心に10種 類以上のミニブタが開発されており、わが国でもオーミ ニとクラウンミニの 2 系統が開発されている。米国で開 発された系統の 1 つに、国立保健研究所 $(\mathrm{NIH})$ で作出 された NIHミニブタがある(Sachsら，1976）。このブ 夕は、ある特定の主要組織適合性複合体 (MHC) 夕イ プに固定されたミニブタであり、新しいミニブタを作出 するための素材として、現在わが国の鹿児島県畜産試験 場に導入され飼育されている。

著者らはこれまで、わが国に飼養されている豚の品種・ 系統を中心に、その遺伝的特性の分析の 1 つとして、血 液型および蛋白質型を調查してきた。ミニブタの系統に ついては、すでにオーミニ(Oishi \& Tomita, 1976), ピッッマンムーア(Oishi \& Tomita, 1976), ゲッチン ゲン(Oishiら，1980a）およびクラウンミニ（大石ら、 1991）の 4 系統の集讨の遺伝的変異を調査し報告してい る。今回は NIH ミニブタの遺伝的位置付けを考察する ために、血液型および血液蛋白質型を調査し、他のミニ ブタなどの豚集団と比較してみた。

Table 1. Gene frequencies at the 20 loci of blood groups and biochemical polymorphisms in NIH miniature pigs

\begin{tabular}{|c|c|c|c|c|c|}
\hline Locus & Allele & Frequency & Locus & Allele & Frequency \\
\hline \multirow[t]{3}{*}{ A $*$} & A & 0 & $\mathrm{Hp}$ & $H p^{l f}$ & 0 \\
\hline & $\mathrm{O}$ & 0.300 & & $H p^{l}$ & 0.400 \\
\hline & - & 0.700 & & $H p^{2}$ & 0.600 \\
\hline \multirow[t]{4}{*}{$\mathrm{E}$} & $E^{\operatorname{agg}}$ & 0 & & $H p^{3}$ & 0 \\
\hline & $E^{b d g}$ & 1.000 & $\mathrm{Cp}$ & $C p^{A}$ & 0 \\
\hline & $E^{\text {edg }}$ & 0 & & $C p^{B}$ & 1.000 \\
\hline & $E^{e f d}$ & 0 & $\mathrm{Am}$ & $A m^{A}$ & 0 \\
\hline \multirow[t]{2}{*}{$\mathrm{F}$} & $F^{a}$ & 0.800 & & $A m^{B}$ & 1.000 \\
\hline & $F^{b}$ & 0.200 & & $A m^{c}$ & 0 \\
\hline \multirow[t]{2}{*}{ G } & $G^{a}$ & 0.632 & PHI & $P H I^{A}$ & 0.350 \\
\hline & $G^{b}$ & 0.368 & & $P H I^{B}$ & 0.650 \\
\hline \multirow[t]{4}{*}{$\mathrm{H}$} & $H^{a}$ & 0.350 & 6PGD & $6 P G D^{A}$ & 1.000 \\
\hline & $H^{b}$ & 0.650 & & $6 P G D^{B}$ & 0 \\
\hline & $H^{a b}$ & 0 & PGM & $P G M^{A}$ & 0 \\
\hline & $H^{-}$ & 0 & & $P G M^{B}$ & 1.000 \\
\hline \multirow[t]{3}{*}{$\mathrm{K}$} & $K^{a}$ & 0.550 & ADA & $A D A^{A}$ & 1.000 \\
\hline & $K^{b}$ & 0.450 & & $A D A^{B}$ & 0 \\
\hline & $K^{-}$ & 0 & & $A D A^{\circ}$ & 0 \\
\hline \multirow[t]{3}{*}{$\mathrm{L}$} & $L^{h k}$ & 0 & $\mathrm{EsD}$ & $E s D^{A}$ & 0.850 \\
\hline & $L^{h}$ & 0 & & $E s D^{B}$ & 0.150 \\
\hline & $L^{-}$ & 1.000 & PSA-1 & $\mathrm{I}^{a b}$ & 0.106 \\
\hline \multirow[t]{2}{*}{$\mathrm{O}$} & $O^{a}$ & 0.106 & & $\mathrm{I}^{a}$ & 0.447 \\
\hline & $O^{-}$ & 0.894 & & $\mathrm{I}^{0}$ & 0.447 \\
\hline \multirow[t]{2}{*}{$\mathrm{Tf}$} & $T f^{A}$ & 0 & PSA-II & $I I^{a}$ & 0.163 \\
\hline & $T f^{B}$ & 1.000 & & $I I^{\circ}$ & 0.837 \\
\hline \multirow[t]{2}{*}{$\mathrm{Pa}$} & $P a^{A}$ & 0.200 & & & \\
\hline & $P a^{B}$ & 0.800 & & & \\
\hline
\end{tabular}

* Frequencies of the three phenotypes

\section{材料および方法}

血液材料は、鹿児島県畜産試験場に南日本グレーンセ ンターを介して導入された $\mathrm{NIH}$ ミン゙タ10頭（雄 6 , 雌 4 ）加採取した。そしてその血液を用いて、赤血球 抗原型 8 座位 (A, E, F, G , H , K , L , O)、血清蛋白 質型 5 座位 ( Tf, $\mathrm{Pa}, \mathrm{Hp}, \mathrm{Cp}, \mathrm{Am}$ )、赤血球酵素型 5 座位(PHI，6PGD，PGM，ADA，EsD)、血清アロ夕 イプ 2 座位（PSA- I , PSA- II ) の合計 20 遺伝子座位 を調査した。これら座位の検出方法は、既報に示したと おりである（大石、1980b, 1980c，1980d: Oishiら， 1979）。

遺伝的特性の分析には、遺伝的変異性を示す 4 つの指 標を用い、また品種間相互の遺伝的類縁関係については、 遗伝的距離係数を用いて分析した。遺伝的変異の指標と しては、遺伝子頻度による均質度指数 (H.I.)、個体当た り、座位当たり平均へテロ接合の割合 $(\overline{\mathrm{H}}) 、$ 多型遺伝 子座の割合 $(\mathrm{P}$ poly $) 、$ 座位当たり対立遺伝子の有効な 数（Ne）を用いた(Nozawaら，1976）。また豚集団間 の遺伝的類縁関係の分析には、Rogers(1972)およびNe i(1975) の遺伝的距離係数を算出し、 Sokal and Sneath(1963)のunwe ighted pair group methodを用 いて枝分かれ図を作成した。

\section{結果および考察}

$\mathrm{NIH}$ ミニブタの血液型および蛋 白質型の遺伝子頻度を表 1 に示した。 調查20座位のうち、NIH ミニブタ は、A, F, G, H, K, O, Pa, Hp, PHI, EsD, PSA-I おょびPSAII 12 座位で多型を示した。そのう ちとくに、K, PHI, PSA-I座位 で個体変異が大きかった。 $\mathrm{NIH}$ ミ ニブタの遺伝子頻度を、これまでに 報告しているオーミニ(Oishi \& Tomita, 1976)、ピッッマンムー ア(Oishi \& Tomita, 1976)、ゲッ チンゲン(Oishiら, 1980a)、クラ ウンミニ（大石ら、1991）の 4 系統 のミニブタのそれらと比較すると、 $\mathrm{A}, \mathrm{H}, \mathrm{K}, \mathrm{L}$ おび $\mathrm{Pa}$ 座位で特徵 を示した。すなわち、A (一)、 $H^{b} 、$ $P a^{\mathrm{B}}$ の多い、 $K^{a} 、 P a^{\mathrm{A}}$ の少ない、そ 
して L座位では $L^{h}$ を的 $L^{-}$のみとう特徴を有してい た。

遺伝子頻度を基にして遺伝的变異を示す指数値を算出 したところ、 NIHミニブタは、遺伝子頻度による均質 度指数(H.I.)が 0.600 、個体当たり、座位当たり平均へ テロ接合の割合 $(\bar{H})$ が 0.226 、多型遺伝子座位の割合 (P poly)が 0.600、座位当たり対立遺伝子の有効な数 (Ne)が 1.292であった。これらの数值を、これまでに 報告しているミニブタ 4 系統のそれら（大石ら、1991） と比較すると、オーミニとクラウンミニより変異性が大 きく、ゲッチンゲンおよびピッマンムーアと同等の変異 性であった。 NIHミニブタの基礎となった個体が 2 頭 である(Sachsら，1976) ことを考えると、予想以上に 遺伝的変異性が大きいといえる。

表 2 に $\mathrm{NIH}$ ミニブタと 17 豚集団の間で計算した平均 遺伝的距離係数を示した。17豚集団の中には、中国系 6 品種（金華豚、梅山豚、民豚、桃園種、小耳種、北京黒 豚)、欧米系 7 品種（ランドレース、大ヨークシャ一、 ハンプシャー、デュロック、バークシャー、中ヨークシャー

Table 2 Genetic distances by Rogers and Nei between NIH miniature pigs and seventeen pig breeds

\begin{tabular}{|c|c|c|}
\hline \multirow{2}{*}{ Breed or strain } & \multicolumn{2}{|c|}{ Genetic distance } \\
\hline & $\mathrm{D}_{\mathrm{R}}^{1}$ & $\mathrm{D}_{\mathrm{N}}^{2)}$ \\
\hline Taoyuan breed & 0.587 & 0.448 \\
\hline Ohmini pigs & 0.575 & 0.422 \\
\hline Jinhua pigs & 0.570 & 0.411 \\
\hline Meishan pigs & 0.534 & 0.353 \\
\hline Short-ear breed & 0.513 & 0.329 \\
\hline Göttingen miniature pigs & 0.504 & 0.318 \\
\hline Min pigs & 0.484 & 0.317 \\
\hline CLAWN miniature pigs & 0.464 & 0.278 \\
\hline Beijing Black pigs & 0.454 & 0.291 \\
\hline Middle Yorkshire breed & 0.430 & 0.226 \\
\hline Duroc breed & 0.424 & 0.241 \\
\hline Hypor bigs & 0.420 & 0.215 \\
\hline Large White breed & 0.407 & 0.213 \\
\hline Berkshire breed & 0.406 & 0.229 \\
\hline Landrace breed & 0.382 & 0.178 \\
\hline Hampshire breed & 0.365 & 0.175 \\
\hline Pitman-Moore miniature pigs & 0.362 & 0.186 \\
\hline
\end{tabular}

\footnotetext{
1) Rogers (1972)

2) Nei (1975)
}

、ハイポー豚)、ミニブタ 4 系統が含まれており、これ らの遺伝子頻度は既報のものを用いた。Rogersおよび Neiの両式に基づく遺伝的距離は、ほぼ似た傾向を示し た。その結果、 NIHミニブタは中国系品種とは明らか に遠い距離を示し、欧米系品種ともそれほど近くはなかっ たが、そのうちランドレース、ハンプシャー、ピッッマ ンムーアとは比較的近い距離であった。これは NIH ミ ニブタが、米国で作出されたミクロネシア起源のホーメ ル系ミニブタの雌と米国インディアナ州の研究所で飼わ れていた雄（品種不明）を基に作出され(Sachsら，197 6)、アジアやヨーロッパ起源でないことが関係している ものと思われた。

$\mathrm{NIH}$ ミニブタと既報17豚品種（表 2 ）の計18品種相 互で算出した遺伝的距離係数を基にして、18品種の遺伝 的類縁関係を示す枝分かれ図を作成した。その結果は、 図 1 (Rogers) と図2（Nei）に示した。なお NIH ミニ ブ夕を除く 17 品種の間の遺伝的距離係数は、既報のもの を用いた(Oishi \& Tanaka, 1992)。Rogersおよび Neiのいずれの遺伝的距離を用いた場合も、NIH ミニ ブタはほぼ同じ位置を占めていた。 すなわち、 $\mathrm{NIH}$ ミニブタは欧米系 品種のグループに属してはいるが、 その中では他のあのと最む離れる位 置にあった。これは前述したように、 アジア系の豚とは完全に起源を異に しているが、欧米系の中ではミクロ ネシア系豚の血を引くということも あり、他の品種とは遠く離れたもの と考えられた。このように他のミニ ブタ系統と比較して、遺伝的には少 し特異な位置を占めるが、その中で は北アメリカのフロリダ半島起源の ピッッマンムーアミニブタと比較的 近いと思われた。 
Ohmini pigs

Taoyuan breed

Jinhua pigs

Meishan pigs

Min pigs

Göttingen miniature pigs

CLAWN miniature pigs

Short-ear breed

Beijing Black pigs

$\mathrm{NIH}$ miniature pigs

Pitmam-Moore miniature pigs

Hampshire breed

Berkshire breed

Large White breed

Middle Yorkshire breed

Duroc breed

Landrace breed

Hypor pigs

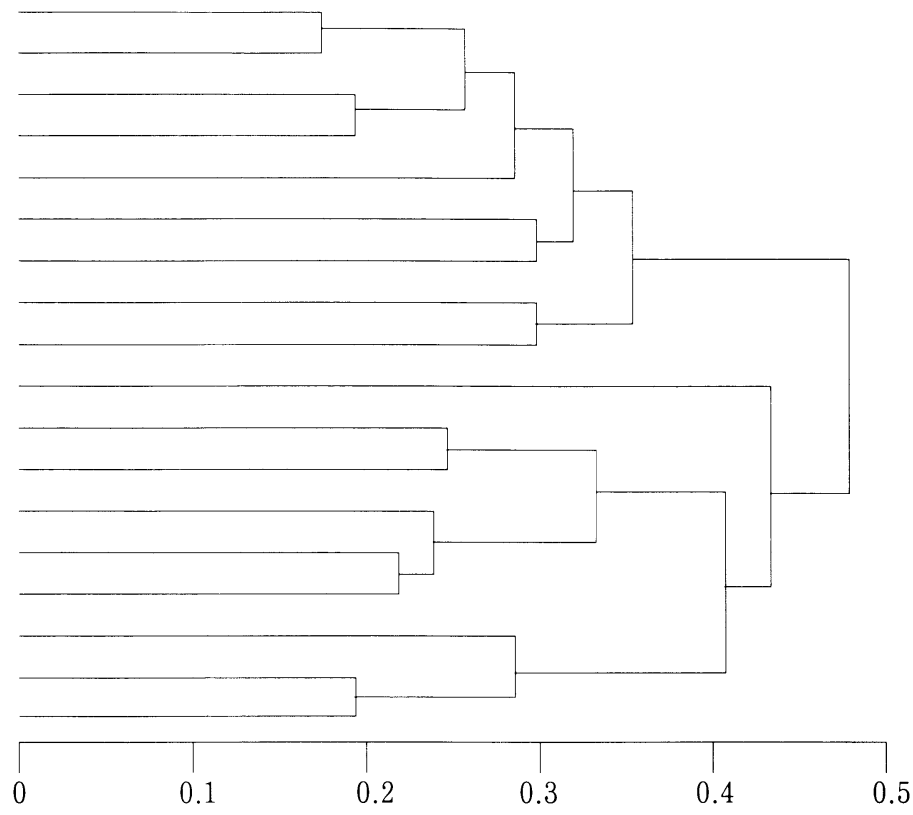

Fig. 1 Dendrogram showing genetic similarities among eighteen pig populations drawn from the Rogers' genetic distance

Ohmini pigs

Taoyuan breed

Short-ear breed

Jinhua pigs

Meishan pigs

Min pigs

Göttingen miniature pigs

CLAWN miniature pigs

Beijing Black pigs

Duroc breed

NIH miniature pigs

Pitman-Moore miniature pigs

Hampshire breed

Berkshire breed

Large White breed

Middle Yorkshire breed

Landrace breed

Hypor pigs

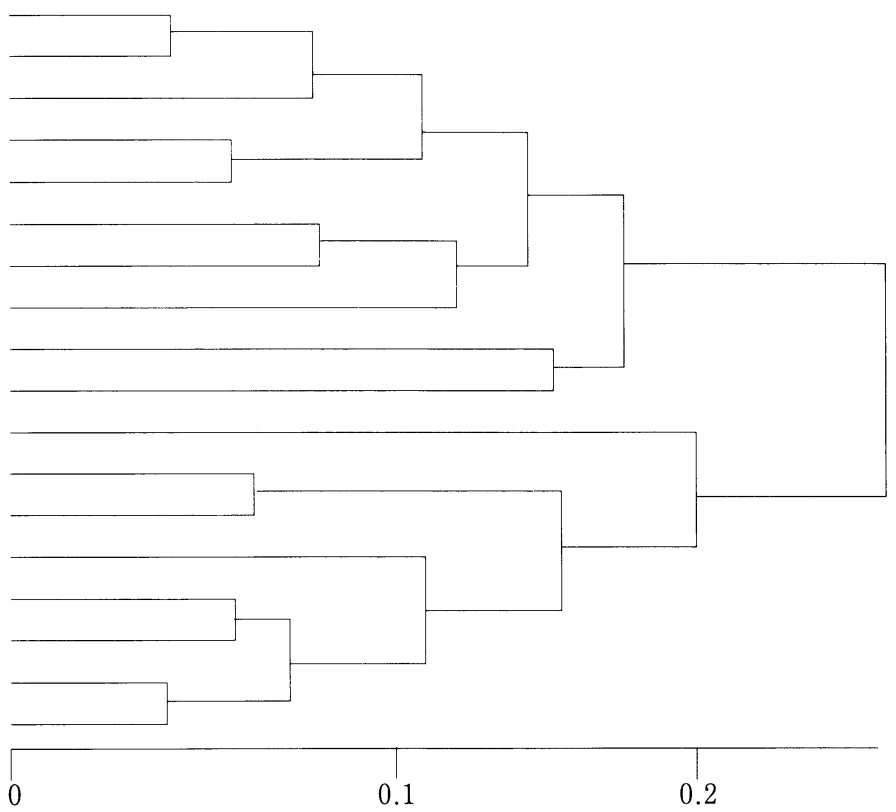

Fig. 2 Dendrogram showing genetic similarities among eighteen pig populations drawn from the Nei's genetic distance 
要約

鹿児島県畜産試験場に導入された NIH ミニブタ 10 頭 から血液を採取、血液型と蛋白質型を調查した。調査し た20座位のうち、 NIH ミニブタは12座位で多型を示し た。他のミニブタ（オーミニ、クラウンミニ、ゲッチン ゲン、ピッッマンムーア）と比較すると、 A, H, K, L および $\mathrm{Pa}$ 座位で特徴がみられた。遺伝子頻度を基に遺 伝的異性を示す 4 指標値 (H.I., $\overline{\mathrm{H}}, \mathrm{P}$ poly, $\mathrm{Ne}$ )を算 出したところ、 NIH ミニブタはミニブタ 5 系統の中で オーミニとクラウンミニより変異性が大きく、ゲッチン ゲンおよびピッッマンムーアと同等の変異性であった。 $\mathrm{NIH}$ ミニブタとこれまでに調查した17豚品種との間で Rogersおよび Neiの式に基づく遺伝的距離を計算した ところ、NIHミニブタは中国系品種とは明らかに遠い 距離を示し、欧米系品種ともそれほど近くはなかったが、 そのうちランドレース、ハンプシャー、ピッッマンムー アとは比較的近い距離であった。18豚集団の遺伝的類縁 関係を示す枝分かれ図を作成したところ、 NIH ミニブ 夕は欧米系品種のグループに属し、その中では他のもの と最も離れる位置を占めていた。

キーワード : NIHミニブタ、血液型、蛋白質型、遗伝 的変異性、遺伝的距離

\section{文献}

Nei,M., 1975. Molecular Population Genetics and Evolution, 288pp. North-Holland Publ. Amsterdam.

Nozawa, K., T. Shotake \& Y. Ohkura, 1976. Blood protein variations within and between the east Asian and European horse populations. Z. Tierzüchtg. Züchtgsbiol. 93:60-74.

Oishi,T. \& T. Tomita, 1976. Blood groups and serum protein polymorphisms in the Pitman-Moore and Ohimini strains of miniature pigs. Anim. Blood Grps biochem. Genet. $7: 27-32$.
Oishi,T., T. Abe \& M. Komatsu, 1979. Three serum allotypic antigens detected in pigs. Jpn. J. Zootech.Sci.50:173-181.

Oishi,T., K. Esaki \& T. Tomita, 1980a. Genetic relationship among Göttingen miniature, Eropean and East Asian pigs investigated from blood groups and biochemical polymorphism. Jpn. J. Zootech. Sci. 51: 226228.

大石孝雄, $1980 \mathrm{~b}$. 豚の血液型と蛋白質多型の研究と応 用（2）II. 赤血球抗原型の判定技術とその分類. 畜産の研究 34:1155-1158.

大石孝雄, 1980c. 豚の血液型と蛋白質多型の研究と応 用 (3) III. 血清蛋白質の判定技術とその分類. 畜 産の研究 34:1263-1266.

大石孝雄, $1980 \mathrm{~d}$. 豚の血液型と蛋白質多型の研究と応 用 (4) IV. 赤血球酵素型の判定技術とその分類. 畜産の研究 34:1503-1506.

Oishi,T., \& K.Tanaka, 1992. Genetic variations of blood groups and biochemical polymorphisms in seven Chinese pig breed. Proc. Intern. Symp. Chinese Pig Breeds p.192-200, Harbin, 1992,8.

大石孝雄・中西喜彦・田中一栄, 1991. 血液型および蛋 白質型によるクラウン系ミニブタの遺伝的分析. 日豚会誌 28:126-132。

Rogers, J.S., 1972. Measures of genetic similarity and genetic distance. University of Texas Pub1. 7213:145-154.

Sachs, D. H., G. Leicht, J. Cone, S. Schwarz, L. Stuart \& S. Rosenbery, 1976. Transplantation in miniature swine I. Fixation of the major histocompatibility complex. Tanaplantaion 22 : 559-567.

Sokal, P.R. \& P.H.A. Sneath, 1963. Principles of Numerical Taxonomy, Freeman, San Francisco and London. 